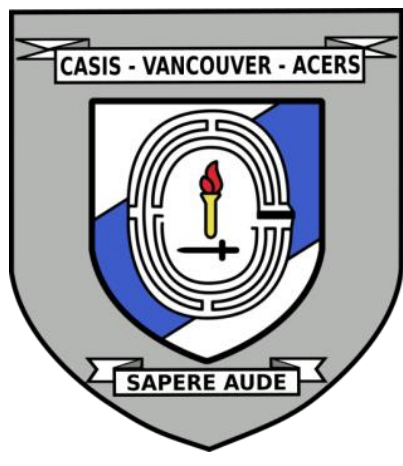

\title{
LEADERSHIP, INTELLIGENCE MANAGEMENT, AND COMPLEX CRISES
}

Date: November 26, 2021

Disclaimer: This briefing note contains the encapsulation of views presented by the speaker and does not exclusively represent the views of the Canadian Association for Security and Intelligence Studies.

\section{KEY EVENTS}

On November 26, 2021, Rear Admiral Richard Kelshall, former CARICOM Regional Advisor, presented on Leadership, Intelligence Management, and Complex Crises at the 2021 CASIS West Coast Security Conference. The key points discussed included the characteristics of effective leadership, problems that might impede good leadership, and the changing nature of leadership. The presentation was followed by a question and answer period with questions from the audience and CASIS Vancouver executives.

\section{NATURE OF DISCUSSION}

\section{Presentation}

The overarching theme of RAdm Kelshall focused on some of the most important leadership lessons he learned throughout his career with the Royal Navy. RAdm Kelshall also discussed what the major problems from leaders are and how leadership continues to change.

\section{Question Period}

During the question and answer period, RAdm Kelshall discussed the evolving nature of leadership and noted what he considers are important leadership traits and the importance of learning from failure. 


\section{BACKGROUND}

\section{Presentation}

RAdm Kelshall began his presentation by highlighting that without good intelligence and leadership, no international laws can prevail even when years of experience and good intentions exist. RAdm Kelshall then provided a number of leadership lessons as he reflected on memorable events at the Britannia Royal Naval College and with the Royal Navy. He stated that it was by simple training exercises from which he drew valuable lessons on leadership.

- Lesson 1: "When you think you are done, that is when you start; you never give up." Leadership is very much like intelligence; to obtain a finished product, it takes a lot of painstaking work. Both leadership and intelligence can lead you down a long, painful road to enlightenment.

- Lesson 2: "Listen to the years of experience. You don't know it all; you never do." There are times when leadership lessons come from those who one is set up to lead.

- Lesson 3: "Leadership requires courage." It is not easy to make difficult decisions, but doing so and most importantly quickly, can make a big difference and sometimes even be the difference between life and death.

- Lesson 4: "If your people do not trust you, they will not follow you." Consequently, be left alone and without any support when facing difficult decisions in one's career.

- Lesson 5: During difficult situations, fear can take over one's ability to perform, but being able to free oneself from it, can have long-lasting impacts in life.

RAdm Kelshall noted that one could argue that the major problem for leaders has always been not having exact, precise, and accurate intelligence. Throughout history, all the great operations and events took place without exact intelligence. In some cases, war was started because of wrong intelligence (e.g., the Civil War and the Gulf War). The reality is that despite the advances of modern technology, exact intelligence can be very difficult to obtain.

RAdm Kelshall concluded his presentation by pointing out that leadership seems to have changed over the years from the brute force of Spartacus and Alexander the Great through all the famous generals and admirals of World War II, to Colonel H. Jones, in the Falklands. New leaders are now referred to as the information warriors, and it would appear that we are now at the brink of the Star Trek age. RAdm Kelshall noted that new leaders, such as the fictional character 
Captain James T. Kirk - who is able to control warp speed, bend space and time, and to understand how different species think - might have different and more complex visions. Therefore, schools and military training academies should be equipped to train future Captain Kirks to handle this leap into the future. However, RAdm Kelshall stated that simple minds like himself, who learn from practical experience, might prefer to hold on to the advice Colin Powell gave him: "Leadership is the ability to get people to follow you anywhere."

\section{Question Period}

When asked what he thought were the key traits of a leader and whether they would change in the future, Admiral Kelshall postulated that leadership is an evolving concept, so it is difficult to project what 'good' leadership will be like twenty years from now. We need to bear in mind that we are the products of the era we live in, and good leader qualities in twenty years are probably going to be very different from the qualities we look for now.

Further, everyone can develop leadership skills through experiences and failures. It is in the moments of failure when we find out what leadership is about; it is about the ability and will to continue despite failing. Leaders climb up the leadership ladder by overcoming failures and admitting they have made a mistake but are determined to fix it. Through overcoming their own failures, leaders become understanding of the people they command. Leaders lead by knowing and understanding their followers' contributions and failures.

\section{KEY POINTS OF DISCUSSION}

\section{Presentation}

- "When you think you are done, that is when you start; you never give up."

- "Listen to the years of experience. You don't know it all; you never do."

- "Leadership requires courage."

- "If your people do not trust you, they will not follow you."

- Fear can take over one's ability to perform, but being able to free oneself from it, can have long-lasting impacts in life.

\section{Question Period}

- Leadership is an evolving concept, so it is difficult to project what 'good' leadership will be like twenty years from now; we are the products of the era we live in.

The Journal of Intelligence, Conflict, and Warfare Volume 4, Issue 3 
- Leaders climb up the leadership ladder by overcoming failures and admitting they have made a mistake but are determined to fix it.

\section{$\Theta \oplus \Theta \Theta$}

EY NC ND This work is licensed under a Creative Commons Attribution-NonCommercial-NoDerivatives 4.0 International License.

(C) (RICHARD KELSHALL, 2022)

Published by the Journal of Intelligence, Conflict, and Warfare and Simon Fraser University

Available from: https://jicw.org

The Journal of Intelligence, Conflict, and Warfare Volume 4, Issue 3 